\title{
Effects of Sensory Stimuli on Postural Control: a Tetraplegic Case Report
}

\author{
Efectos de Estímulos Sensoriales en el Control Postural: Reporte de caso en un Tetraplégico \\ "Valeska Gatica R.; "*dith Elgueta C. \& **** Ramón Valdés M.
}

GATICA, R. V.; ELGUETA, C. E. \& VALDÉS, M. R. Effects of sensory stimuli on postural control: a tetraplegic case report. Int. J. Morphol., 26(4):809-812, 2008.

SUMMARY: During sessions of physical therapy, a tetraplegic patient with incomplete spinal cord section at C5 level was found to have changes in the posture post intervention. The therapy consisted of tactile stimulation in specific points of his body to generate reflex patterns of muscle activation (Vojta therapy principles). To quantify these postural changes in the subject, the center of pressure displacement in sitting posture was measured. An analysis of the changes observed in postural control through fourteen months of followup is presented and discussed in the report bellow.

KEY WORDS: Specific manual press stimulus (SMPS); Static posturographic platform; Postural control.

\section{INTRODUCTION}

The sensory stimuli (touch, vibration or pressure) are crucial to trigger the activation of specific receptors located in the skin, joints, tendons or muscles. This information, along with the visual and vestibular data, is crucial for controlling human posture in several variations and / or environmental conditions (Peterka \& Loughlin, 2004; Gage et al., 2003, 2007).

The somatosensory system is responsible for the manifestation of proprioception, defined as the sensitivity of postural and movement of the limbs and the rest of the body without using the sense of sight (Kandel et al., 2001). In this regard, it has been shown that proprioception from the ankles and the soles of the feet helps with postural stability in stand, that condition is diminished in subjects who suffer diabetic neuropathy (Nashner et al., 1982; Diener et al., 1984; Redfern \& Furman, 1994; Simoneau et al., 1996; van Deursen et al., 1998).

Moreover, it is important to notice that the perceived quality of a stimulus is determined by the property of their receivers (triggering threshold and adaptation) and the location, i.e. the distance towards its central targets (Berenberg et al., 1987; Van Asten et al., 1988a, 1988b; Holme et al., 1999; Rozzi et al., 1999). For example, visual information is picked up by receivers that are located in the retina and the distance travelled until the crust (occipital and temporal) is much smaller than the distance traveled by sensory stimuli perceived in the foot (Wolosley et al., 1996). Therefore, the frequency of firing the potential generators (also known as receptor potentials) is substantially lower in the visual system in the order of $<0.1 \mathrm{~Hz}$ with respect to the somatosensory, >1,0 Hz (Lephart et al., 1998; Kavounoudias et al., 2001; Redfern et al., 2001).

Each sensory system presents optimal frequency ranges that almost overlap each other, and the integration of those signals requires a correct processing of inputs at the central level to ensure a good postural control (Table I) (Redfern et al., 2001).

In the case of patients with spinal cord damage, the ascent, as well as the integration of sensory inputs to the central nervous system is interrupted, altering muscle responses and thereby the maintenance of postural control. This is one of the problems to be solved by rehabilitation medicine; understanding which sensory mechanisms facilitate better postural control in individuals with spinal cord injury (Holm et al., 2002; Eversull et al., 2001).

* Master Science Major Physiology, Bachelor in Physical Therapy, Faculty of Health Sciences, Laboratory of Physiology, School of Physical Therapy. Universidad de Talca, Chile.

** Bachelor in Physical Therapy, Faculty of Health Sciences, Laboratory of Biomechanics, School of Physical Therapy. Universidad de Talca. Chile.

**** Bachelor in Physical Therapy, Faculty of Health Sciences, School of Physical Therapy. Universidad de Talca, Chile. 
Table I. Optimal frequency ranges of stimulation.

\begin{tabular}{ccccc}
\hline $\begin{array}{c}\text { Sensory } \\
\text { systems }\end{array}$ & Vision & $\begin{array}{c}\text { Vestibular } \\
\text { 0toliths }\end{array}$ & $\begin{array}{c}\text { Vestibular semicircular } \\
\text { canals }\end{array}$ & Somatosensation \\
\hline Frequencies & $<0,1 \mathrm{~Hz}$ & $0,1-0,5 \mathrm{~Hz}$ & $0,5-1,0 \mathrm{~Hz}$ & $>1,0 \mathrm{~Hz}$ \\
\hline
\end{tabular}

Thus, our objective was to analyze the specific manual press stimulus (SMPS) that generate changes in postural control in a subject who has suffered an incomplete spinal cord section at fifth cervical vertebra (C5) level.

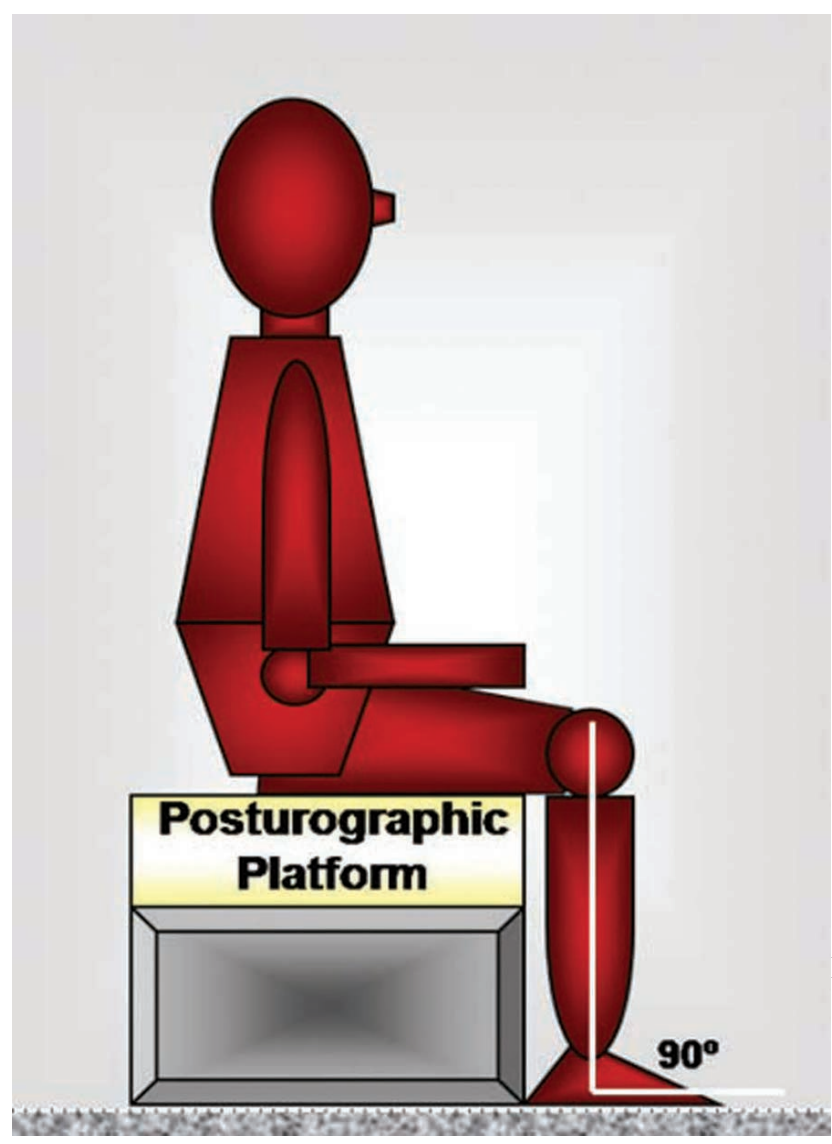

\section{MATERIAL AND METHOD}

A prospective case study of a 21 year-old tetraplegic patient, with incomplete spinal cord section at C5 level, was considered. According to American Spinal cord Injury Association (ASIA index), he had 33 motor-score and 30 sensory-score. The subject gave written consent approved by the institutional review board of Universidad de Talca. The patient was evaluated sitting in a static force platform for five minutes before and after the intervention; during the intervention the patient received pressure stimuli at specific points of his body (Figs. 1 and 2) to generate reflex patterns of muscle activation using Vojta Therapy principles from day 465 after spinal cord section, once a month for fourteen months. The evaluation consisted of two phases. In the first phase, the subject had to keep his eyes right in front without visual feedback; the second phase was similar to the previous one but having his eyes closed. Signals obtained from the displacement of pressure center during the test were analyzed by the Wavelet Transform in order to determine the intensity of each frequency band $(4 \mathrm{~Hz}, 2 \mathrm{~Hz}, 1 \mathrm{~Hz}, 1 / 2 \mathrm{~Hz}, 1 / 4 \mathrm{~Hz} 1 / 8$ $\mathrm{Hz}$ and $1 / 16 \mathrm{~Hz}$ ) and the total intensity of the frequency bands (TIB).

Fig. 1. The patient was evaluated sitting in a static force platform.

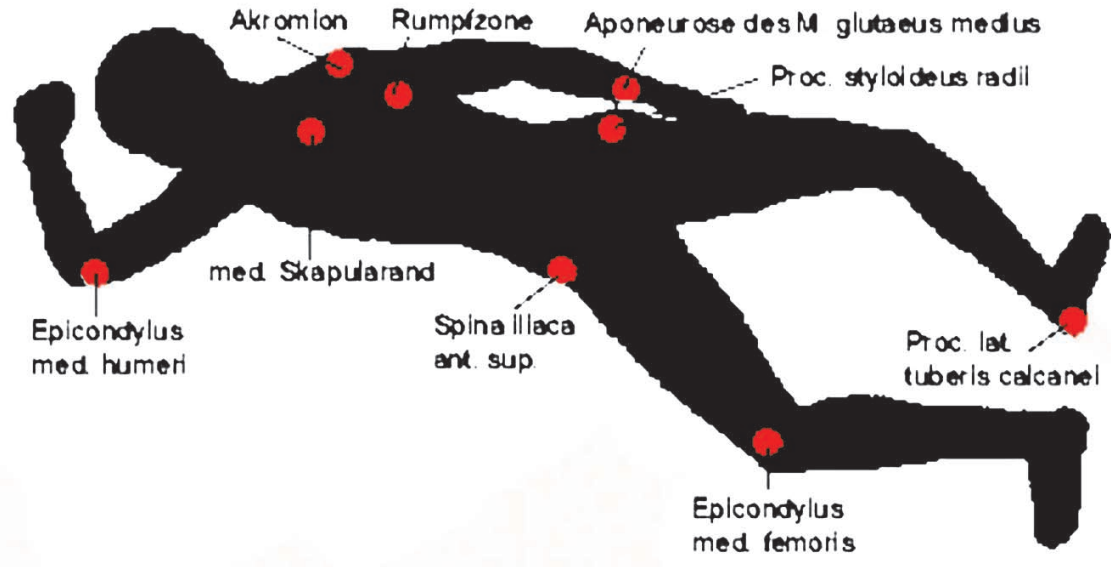

Fig. 2. Shows the SMPS points used with the patient in different positions during the therapy. Decubitus Supino position used Rumpfzone, Spina Iliaca ant. Sup. bilaterally; Decubitus Lateral position used: Medium Skapurland, Rumpfzone, Iliaca ant. Sup. Bilateral. Each stimulus of press was used for approximately tree minutes. 


\section{RESULTS}

We analyzed only nine of the fourteen evaluations for methodological reasons. Lower levels of TIB were obtained in all evaluations in which the pre-intervention evaluation was compared with post-intervention evaluation with eyes opened (mean $+\mathrm{SD}) 0.0065+0.003$ to $0.0066+$ $0.003 \mathrm{~J}$ and eyes closed $0.0129+0.012$ to $0.01+0.007 \mathrm{~J}$ phases (Fig. 3). A decrease was found in six of the nine evaluations, in which the pre-intervention was compared with post-intervention evaluations in the closed-eyed phase on the $1 / 16 \mathrm{~Hz}$ band but it wasn't found in the open-eyed phase in which only four of the nine shown lower values were found (Fig. 4).

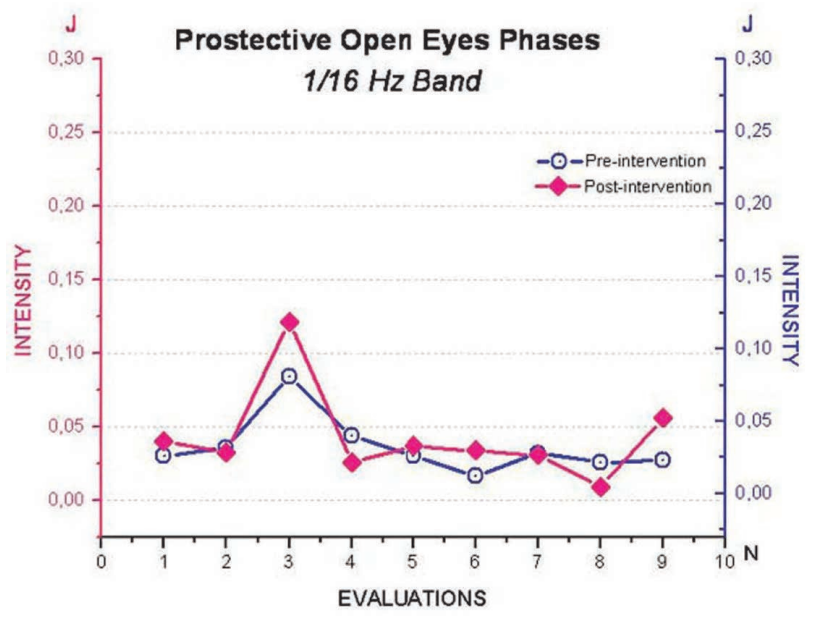

Fig. 3. Shows the comparison of the pre-intervention with the postintervention evaluations in the open-eyed phase on the $1 / 16 \mathrm{~Hz}$ frequency band.

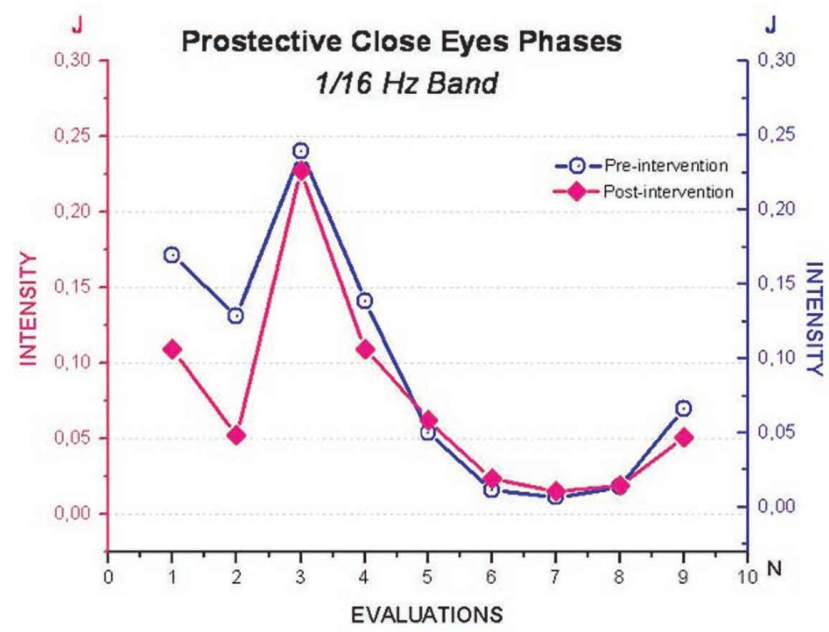

Fig. 4. Shows the comparison of the pre-intervention with the postintervention evaluations in the closed-eyed phase on the $1 / 16 \mathrm{~Hz}$ frequency band.

\section{DISCUSSION}

Lower levels of ETR obtained with eyes open, as well as eyes closed could be understood as change in maintaining balance at reflex/automatic levels. This would be due to lower levels of energy in post-stimulation in the low frequency bands, predominantly in the $1 / 16 \mathrm{~Hz}$, which would be appropriate that the visual inputs were not the pathway of regulations of this response (Paulus et al., 1984; Peterka \& Benolken, 1992). Therefore, SMPS could indicate an activation of a reflex/automatic mechanism or patterns at a medullar lever (center generator patterns) that could improve the postural control in a tetraplegic by the activation of receptors of low threshold (mechanic and proprioceptive), which act at an involuntary level firing the activation of diverse descending unharmed circuits (or internal patterns), that would produce an increase in the stiffness of the undamaged muscles of the upper body (posterior chain) to control the upper body sway and, therefore, improve the sitting postural control (Horak \& Nashner, 1986; Horak et al., 1989; Gedalia et al., 1999).

As it is known any change in the stiffness joints would affect the balance control, in this case, it may be an improvement in the postural control in space.

\section{ACNOWLEDGEMENTS}

We would like to thank DI (Department of Investigation) for the financial grant of the project $\mathrm{N}^{\circ} 504$, VAC 600430 and to the School of Physical Therapy of Universidad de Talca for the financial support to this publication and Mr. Andrew Philominraj director of Dirección de Relaciones Internacionales of Universidad de Talca, Chile.

GATICA, R. V.; ELGUETA, C. E. \& VALDÉS, M. R. Efectos de estímulos sensoriales en el control postural: Reporte de caso en un tetrapléjico. Int. J. Morphol., 26(4):809-812, 2008.

RESUMEN: Durante las sesiones de terapia física, en un paciente tetrapléjico con sección incompleta de la médula espinal a nivel C5, se encontró que hubo cambios en la postura, posterior a la intervención. La terapia consistió en estimulación táctil en puntos específicos del cuerpo para generar patrones reflejos de activación muscular (principios de la terapia Vojta). Para cuantificar estos cambios de postura en el sujeto, se midió el desplazamiento del centro de gravedad en la posición sentada. Un análisis de las variaciones observadas en el control postural, a través de catorce meses de seguimiento, se presentan y discuten en el siguiente informe.

PALABRAS CLAVE: Estímulo específico de presión manual (EEPM); Plataforma de posturografía estática; Control postural. 


\section{REFERENCES}

Berenberg, R. A.; Shefner, J. M. \& Sabol, J. J. Quantitative assessment of position sense at the ankle: a functional approach. Neurology, 37(1):89-93, 1987.

Diener, H. C.; Dichgans, J.; Guschlbauer, B. \& Mau, H. The significance of somatosensation on postural stabilization as assessed by ischemia. Brain Res., 296:103-9, 1984.

Eversull, E. B. S.; Solomonow, M.; Bing He Zhou, E. E.; Baratta, R. V. \& Zhu, M. P. Neuromuscular neutral zones sensitivity to lumbar displacement rate. Clin. Biomech. (Bristol, Avon), 16(2):102-13, 2001.

Gage, W. H.; Frank, J. S.; Prentice, S. D. \& Stevenson, P. Organization of postural responses following a rotational support surface perturbation, after TKA: sagittal plane rotations. Gait Posture, 25(1):112-20, 2007.

Gage, W. H.; Winter, D. A.; Frank, J. S. \& Adkin, A. L. Kinematic and kinetic validity of the inverted pendulum model in quiet standing. Gait Posture, 19(2):124-32, 2003.

Gedalia, U.; Solomonow, M.; Zhou, B. H.; Baratta, R. V.; Lu, Y. \& Harris, M. Biomechanics of increased exposure to lumbar injury due to cyclic loading: II. Recovery of reflexive muscular stability with rest. Spine, 24(23):2461-7, 1999.

Holm, S.; Nidal, A. \& Solomonow, M. Sensorimotor control of the spine. J. Electromyogr. Kinesiol., 12(3):219-34, 2002.

Holme, E.; Magnusson, S. P.; Becher, K.; Bieler, T.; Aagaard, P. \& Kjaer, M. The effect of supervised rehabilitation on strength, postural sway, position sense and re-injury risk after acute ankle ligament sprain. Scand. J. Med. Sci. Sports, 9(2):104-9, 1999.

Horak, F. B.; Diener, H. C. \& Nashner, L. M. Inluence of central set on human postural responses. J. Neurophysiol., 62(4):84153, 1989.

Horak, F. B. \& Nashner, L. M. Central programming of postural movements: adaptation to altered support-surface configurations. J. Neurophysiol., 55(6):1369-81, 1986.

Kandel, E. R.; Schwartz, J. H. \& Jessell, T. M. Principles of neural science. New York, McGraw-Hill, 2001.

Kavounoudias, A.; Roll, R. \& Roll, J. P. Foot sole and ankle inputs contribute jointly to human erect posture regulation. J. Physiol., 532(3):869-78, 2001.

Lephart, S. M.; Pincivero, D. M. \& Rozzi, S. L. Proprioception of the ankle and knee. Sports Med., 25(3):149-55, 1998.

Nashner, L. M.; Black, F. O. \& Wall, C. $3^{\text {rd }}$. Adaptation to altered support and visual conditions during stance: patients with vestibular deficits. J. Neurosci., 2(5):536-44, 1982.
Paulus, W. M.; Stuabe, A. \& Brandt, T. Visual stabilization of posture. Physiological stimulus characteristics and clinical aspects. Brain, 107(4):1143-63, 1984.

Peterka, R. J. \& Benolken, M. S. Role of somatosensory and vestibular cues in attenuating visually-induced human postural sway. In: Woollacott, M. \& Horak, F. (Eds.). Posture and gait: control mechanisms. Oregon, University of Oregon, 1992. pp.272-5.

Peterka, R. J. \& Loughlin, P. J. Dynamic regulation of sensoriomotor integration in human postural control. J. Neurophysiol., 91(1):410-23, 2004.

Redfern, M. S. \& Furman, J. M. Postural sway of patients with vestibular disorders during optic flow. J. Vestib. Res., 4(3):22130, 1994.

Redfern, M. S.; Yardley, L. \& Bronstein, A. M. Visual influences on balance. J. Anxiety Disord., 15(1-2):81-94, 2001.

Rozzi, S. L.; Lephart, S. M.; Sterner, R. \& Kuligowski, L. Balance training for persons with functionally unstable ankles. $J$. Orthop. Sports Phys. Ther., 29(8):478-86, 1999.

Simoneau, G. G.; Derr, J. A.; Ulbrecht, J. S.; Becker, M. B. \& Cavanagh, P. R. Diabetic sensory neuropathy effect on ankle joint movement perception. Arch. Phys. Med. Rehabil., 77(5):453-60, 1996.

Van Asten, W. N.; Gielen, C. C. \& Denier van der Gon, J. J. Postural movements induced by rotations of visual scenes. J. Opt. Soc. Am. A., 5(10):1781-9, 1988a.

Van Asten, W. N.; Gielen, C. C. \& Deinier van der Gon, J. J. Postural adjustments induced by simulated motion of differently structured environments. Exp. Brain. Res.,73(2):371-83, 1988b.

van Deursen, R. W.; Sanchez, M. M. ; Ulbrecht, J. S. \& Cavanagh, P. R. The role of muscle spindles in ankle movement perception in human subjects with diabetic neuropathy. Exp. Brain Res., 120(1):1-8, 1998.

Wolosley, C. J.; Sakellari, V. \& Bronstein, A. M. Reorientation of visually evoked postural responses by different eye-in-orbit and head-on-trunk angular positions. Exp. Brain Res., 111(2):283-8, 1996.

\section{Corresponce to:}

Professor Valeska Gatica Rojas

School of Physical Therapy, Universidad de Talca

Aveneu Lircay s/n

Talca - CHILE

Email: vgatica@utalca.cl

Received: 17-07-2008

Accepted: 22-09-2008 